\title{
UBR5 wt Allele
}

National Cancer Institute

\section{Source}

National Cancer Institute. UBR5 wt Allele. NCI Thesaurus. Code C111929.

Human UBR5 wild-type allele is located in the vicinity of $8 \mathrm{q} 22$ and is approximately $161 \mathrm{~kb}$ in length. This allele, which encodes E3 ubiquitin-protein ligase UBR5 protein, is involved in the initiation of protein degradation. 